\title{
Information Access for Development: A Case Study at a Rural Community Centre in South Africa
}

\author{
SJ Jacobs and ME Herselman \\ Tshwane University of Technology, South Africa
}

\author{
jacobssj@tut.ac.za herselmanme@tut.ac.za
}

\begin{abstract}
This paper examines the theoretical linkage between ICT and advances within a business in a rural community in the North West Province of South Africa. Various aspects are addressed like services and service delivery mechanism, locally adapted content and context, realistic approach to technologies and financial sustainability. A rural community centre in Itsoseng was investigated regarding the above aspects and the results are provided. It became apparent that if these above aspects are not seen as integrated activities within a rural community, success is difficult to achieve. Success in providing human and institutional capacities that harness information and knowledge is imperative.
\end{abstract}

Keywords. digital divide, CT hub model, rural areas, South Africa

\section{Introduction}

Interaction between humans and computers has greatly increased as we embark on the $21^{\text {st }}$ century. Ability to access computers and the Internet has become increasingly important to completely immerse oneself in the economic, political and social aspects of the world. However not every business have access to this technology. In the global digital information age those who are unable to access the Internet through ICTs are increasingly disadvantaged in their access to information. Government policies in South Africa (ICT charter) are being established which attempt to ensure that all citizens have the opportunity to access and effectively use ICT in order to enable them to participate fully in the educational, social and economic activities and democratic processes (Cullen, 2002, p.2). New and powerful technologies can also promote efficiency of enterprises competing in the global economy and public sector service delivery (CIDAs strategy, 2005, p. 5). ICTs are now a standard operating tool in today's information society and the information that ICTs carry is increasingly becoming an important factor of production. Moreover teledensity and power supply are generally accepted as drivers of economic growth in developing countries (Saunders, Warford \& Wellenius, 1994 as cited in CIDA 2005). In the poor and under-

Material published as part of this publication, either on-line or in print, is copyrighted by the Informing Science Institute. Permission to make digital or paper copy of part or all of these works for personal or classroom use is granted without fee provided that the copies are not made or distributed for profit or commercial advantage AND that copies 1) bear this notice in full and 2) give the full citation on the first page. It is permissible to abstract these works so long as credit is given. To copy in all other cases or to republish or to post on a server or to redistribute to lists requires specific permission and payment of a fee. Contact Publisher@InformingScience.org to request redistribution permission. developed regions or countries one has the gap that exist between those who have access to technologies and those who do not, commonly referred to as the digital divide. This divide can result in information and knowledge poverty. However it has to be noted that technology in itself does not solve social and economic discrepancies within societies and can often exacerbate them. Massive 
growth in the use of ICTs in India for instance has had no impact at all on what has been described as "the highest concentration of poverty in the world" (Rao, 2003, p. 3). Also new technologies do not always replace the old. They may co-exist and in doing so enhance the range of human experience without necessarily diminishing the experience of those who do not use them, preferring older technologies (telephone, radio) to achieve the same ends. The contribution of using the Internet in rural communities seems to be on sharing global knowledge and expertise to help support their initiatives against poverty and disease, better communication with trading partners through e-commerce and the ability to trade opportunities and to use low wage economy and different time zones to monitor and process transactions around the globe (Cullen 2002:3).

\section{Finances and ICTs Adoption in Rural Businesses}

In 1990s Cosh \& Hughes (2000) indicated that the financial and employment performance of small rural businesses deteriorated relative to urban ones. This climate has stimulated the debate on how best to support rural business activity. Roberts (2002) and Smallbone, North, Baldock, and Ekamen (2002) list barriers to growth in rural businesses and indicate that there is a slower adoption of ICTs among these type of businesses. Friedlander (2001), Roberts (2002) and Warren (2000) emphasize the importance of limited access to communications networks and technology, high usage costs and limited relevant content as reasons for the slow adoption to ICTs in these businesses. Smallbone et al. (2002) and Freshwater (2001) acknowledge an alternative case that there are gaps in labour force skills and reluctance on the part of rural business owner-managers to adapt to the changing environment. In these papers rural businesses are slow to understand the benefits of ICT adoption.

According to Cullen (2002) and Rao (2003) the following factors can be highlighted for preventing rural businesses for reaping the benefits of ICTs and can also be seen as barriers to using technology:

- Physical access (lack of a robust telecommunications infrastructure, computers and connectivity) and costs it involves

- Lack of awareness of the benefits of ICTs

- Lack of ICT skills and support

- Attitudinal barriers like cultural and behavioral attitudes towards technology

- Language barriers in using the Internet especially if English is not the first language

- Lack of local language information products or content, especially tailored to the assimilation capacities of rural people or interesting and relevant to them

- Non-availability of governmental information online

- Lack of motivation to use information over the Internet

These above factors can play a role in a rural community and governments also need to be informed of these in order to ensure they are diminished for better results.

Low demand in rural businesses can be result of information failures and market conditions. Deakins, Galloway \& Mochrie (2004) further state that global orientation is the best predicator of rural business growth and rapid ICT adoption is also much more likely within globally orientated businesses. Rural businesses therefore have to strategise themselves for the global market and ensure that information is distributed correctly in order to ensure financial sustainability. Apart from the finances and slow adoption in rural communities, innovation, taking risks and policy issues further hampers development. 


\section{Innovation, Risks and Policy}

The conventional model of small business behaviour which underpin most rural policy interventions treats innovation generally as the driver of employment and income growth. Thus ICT adoption deserves support because of its potential impact on the health of both individual businesses and the rural economy. Yet, the previous discussion of the role of global or growth orientation of rural businesses suggest that ICTs are more likely to have an important role in terms of transforming businesses' behaviour if their role is innovative, at least at the level of the firm. This argument is also appearing in the policy literature. Fuller and Southern (1999) and Naidoo (2005) criticize those governmental policies based on 'technology push' as being unlikely to engage with the business development needs of rural businesses. Despite the governmental intervention the value of imaginative ICT adoption in rural businesses cannot be underestimated. Friedlander (2001) and Cullen (2002) argue that the content of technologies must engage with potential users' needs in order for it to be adopted. Mitchell and Clark (1999, p. 45) has found in their studies that locally orientated rural businesses make very little use of computing facilities, typically using computers for 'word processing, financial management and producing accounts". These limited usages of ICTs limit the possibility of ICTs being used in innovative ways. Warren (2000) argues that for micro-businesses in particular, limited use of ICTs can be a rational response to the business environment. Thus policy interventions are more likely to be successful where they meet the clients of rural businesses, are easily accessible, have flexible delivery mechanisms, provide services from a one-stop-shop and achieve sustainability, so that they are not reliant upon continued public funding (Deakins, Galloway \& Mochrie, 2004, p. 7).

As Ramirez (2001) states that for communities to be sustainable they need to define what they want to be, where they want to go and ICT are tools to be harnessed towards those agreements. The value of ICTs should be found in community-owned activities and communication spaces where issues of importance (content) to the community are addressed.

Huggins and Izushi (2002) argue that the sort of imaginative and innovative way of using ICTs that enable businesses to obtain the full benefit of adoption is more likely to occur in environments in which ICTs are ubiquitous. Facilities like community centers can assist by increasing user's familiarity with technology in non-threatening, social settings. The design of policy interventions should therefore be guided by analysis of the nature of the causes of slow adoption as well as an understanding of the environment within which rural businesses work. Evidence of the following can be found: slow roll-out of high bandwidth networks in rural areas, limited training facilities, the paucity of exemplars of rapid adoption and the uncertainty of how to use ICTs to transform business activity. Such failures of demand are likely to prove more intractable for policy makers. Rather than simply presenting rural businesses with a menu of technologies to choose from, public agencies have to assist businesses identify ways in which ICTs adoption and use can enhance their ongoing activities, so that limited process innovation may occur.

The role of infrastructure upgrades to assist rural businesses in becoming economically viable is only possible through regulatory mechanisms, governmental support and partnerships (Ramirez, 2001). A community development approach to rural and remote ICT development, calls for the integration of economic and social development goals. In other words, while the benefits of ICTs for rural businesses must be presented as economically feasible, at the same time they must engage social and regional developmental policy dimensions. The focus on the infrastructure should also therefore include a focus on the info-structure where access to technology can allow for rural businesses to supply their communities with information that they might be interested about.

Information is critical to development; thus ICTs as means of sharing information are not simply a connection between people, but a link in the chain of the development process itself. There is now considerable evidence that telecommunications contributes to socio-economic development 
(Conradie, Morris \& Jacobs, 2003; Gómez \& Hunt 1999; Mncube, 2003); studies have shown that access to information through telecommunications can facilitate many development activities including agriculture, fisheries, commerce, tourism, shipping, education, health care and social services (Gómez \& Hunt ,1999, p. 149; Sebusang \& Masupe, 2003).

In general, the ability to access and share information can contribute to the development process by improving:

- efficiency, or the ratio of output to cost;

- effectiveness, or the quality of products and services;

- equity, or the distribution of development benefits throughout the society.

The purpose of the paper was to establish which information access a rural community needs in order to develop itself to become self sustainable. A community centre is a means to provide access to tools to create, access, and share information. Thus, if the contribution of a centre to the development of a community is understood, the need exist to understand what information is needed in the communities, and what other factors may influence the initiation and impact of activities that may be considered developmental (from economic, social, cultural and/or political perspectives).

\section{Research Methodology}

In order to determine whether a rural community centre can support the community with relevant content and service delivery in an ICT based environment with financial success, a qualitative research methodology approach was selected. The research data was obtained through the interview process, site visits and questionnaires used during this study at the Ikageng community centre in Itsoseng. This is a rural community located between Lichtenburg and Mafikeng in the North West Province of South Africa.

The data collection process utilise questionnaire sets to acquire information on the current services offered and problems experienced with the delivery process of these services.

The content of the questionnaires (step 3) focused on the main operational components and/or business areas of a community centre, namely: telecentre services, desktop publishing services, training services and business support services. The information gathered was used to design a specific management model for the Itsoseng community (for the use in the Ikageng rural community centre) based on the needs identified from the questionnaires.

The last step was to discuss the proposed management model with the community centre management and staff before computerising the paper model. The data obtained during this process through interviews and informal discussions was used to support the concept multi-media prototype model. The concept prototype model was tested within the same community centre and the data obtained through questionnaires and interviews was used as inputs towards refining the prototype. The prototype should be adaptable to any other community centre with similar needs.

The participants for this study included both the management $(n=4)$ and the staff $(n=9)$ at the Ikageng community centre in Itsoseng in South Africa. They had to each complete a questionnaire and focus group interviews were conducted in order to clarify and verify certain information. It is important to understand that what was done during this study was to conduct interviews and questionnaires in order to determine needs of the community and to create a prototype that was responsive to a specific community's needs and circumstances.

This means it is not necessarily applicable to other community centres, unless exactly the same needs and circumstances apply. What exists is an electronic model that can be introduced into a 
new community and then fine-tuned to the needs and circumstances of that new community by means of a similar process.

\section{The Results}

The services offered within the rural community centre are listed in Table 1 according to the key operational areas.

Table1: Current Services Offered by the Ikageng Community Centre

\begin{tabular}{|c|c|}
\hline Key Operational Area & Services Offered within this Operational Area \\
\hline Telecentre Services & $\begin{array}{ll}\text { - } & \text { Sent Faxes } \\
\text { - } & \text { Receive Faxes } \\
\text { - } & \text { E-mail } \\
\text { - } & \text { Internet }\end{array}$ \\
\hline $\begin{array}{l}\text { Desktop Publishing } \\
\text { Services }\end{array}$ & $\begin{array}{l}\text { - } \text { Content Creation } \\
\text { - } \text { Publication } \\
\text { - } \text { Photo Copying } \\
\text { - } \text { Typing } \\
\text { - } \text { Printing }\end{array}$ \\
\hline $\begin{array}{l}\text { Business Support } \\
\text { Services }\end{array}$ & $\begin{array}{ll}\text { - } & \text { Compile Business Plans } \\
\text { - } & \text { Marketing Services } \\
\text { - } & \text { Financial Services }\end{array}$ \\
\hline Government Services & - $\quad$ Skills Development \\
\hline Training Services & $\begin{array}{ll}\text { - } & \text { Introduction to Computers } \\
\text { - } & \text { Microsoft Word } \\
\text { - } & \text { Microsoft Excel } \\
\text { - } & \text { Microsoft Power Point } \\
\text { - } & \text { Microsoft Access } \\
\text { - } & \text { Junior Training (school kids - mathematics) }\end{array}$ \\
\hline Other Services & $\begin{array}{l}\text { - Complete Tender Applications for Government } \\
\text { Tenders }\end{array}$ \\
\hline
\end{tabular}

Management and staff of the community centre were asked: "What other forms of support could be offered through the centre to meet the community members' needs and expectations?”. The responses were the following:

- The centre needs a support system that can assist with the management of training material, training courses, store of standard templates to support customers' requirements (e.g. curriculum vitae and fax templates), etc.

- The centre could do with an information management system that contains general information concerning basic health care, educational, and agricultural content. This could be in the form of links to websites or a software packages that contain some of these basic content. 
The Table 2 summarizes the information needs of the centre staff and management with regards to services offered to the community members. It is categorized according to the operational components as identified above.

Table 2: Summary of Information needs from Ikageng Community Centre Management and Staff

\begin{tabular}{|c|c|c|}
\hline $\begin{array}{l}\text { Centre Operational } \\
\text { Component }\end{array}$ & $\begin{array}{c}\text { Centre Management } \\
\text { Response }\end{array}$ & $\begin{array}{l}\text { Centre Staff } \\
\text { Response }\end{array}$ \\
\hline Telecentre Services & $\begin{array}{l}\text { - Standard calculation } \\
\text { sheets for example } \\
\text { computer and Internet } \\
\text { usage, faxing and } \\
\text { phone call services. } \\
\text { - Daily general checklist } \\
\text { when opening and } \\
\text { closing the Centre. }\end{array}$ & $\begin{array}{l}\text { - Standard templates to add customer } \\
\text { content. } \\
\text { - Standard financial recording and re- } \\
\text { porting forms. } \\
\text { - Information with regard to the Internet } \\
\text { and e-mail terminologies (ex. WWW, } \\
\text { using search engines, etc.) }\end{array}$ \\
\hline $\begin{array}{l}\text { Desktop Publishing } \\
\text { Services }\end{array}$ & $\begin{array}{l}\text { Not sure, ask the staff } \\
\text { working with those ser- } \\
\text { vices. }\end{array}$ & $\begin{array}{l}\text { - Standard CV templates } \\
\text { - Interview tips on for example "what an } \\
\text { interview looks like for the candi- } \\
\text { date?" or "how to act during an inter- } \\
\text { view" or "asking the right questions } \\
\text { during the interview" etc. } \\
\text { - List of shortcut keys for word proces- } \\
\text { sors and spreadsheets. } \\
\text { - Short description on what a computer, } \\
\text { word processor, spreadsheets pub- } \\
\text { lishing and presentation is that they } \\
\text { can give to their clients when con- } \\
\text { fronted with these terminologies. }\end{array}$ \\
\hline Training Services & $\begin{array}{l}\text { - Need more Computer } \\
\text { Based training material } \\
\text { to assist the Centre } \\
\text { staff with training and } \\
\text { continuous improve- } \\
\text { ment of skills. }\end{array}$ & $\begin{array}{l}\text { - Content with regard to training on } \\
\text { Microsoft Office, Internet and e-mail } \\
\text { Usage, etc. } \\
\text { - List of Computer Based Training ma- } \\
\text { terial on the market that they could } \\
\text { use to train customers on operating } \\
\text { systems, Web Page Publishing, Busi- } \\
\text { ness Analysis, Project Management } \\
\text { and Presentation Skills. } \\
\text { - Software packages that can assist } \\
\text { children in the community to develop } \\
\text { their mathematical skills. }\end{array}$ \\
\hline $\begin{array}{l}\text { Business Support } \\
\text { Services }\end{array}$ & $\begin{array}{l}\text { - Need a step-by-step } \\
\text { instruction sheet that } \\
\text { could be used when } \\
\text { analysing customers } \\
\text { business and drawing } \\
\text { up business plans. } \\
\text { - Information regarding } \\
\text { trademarks, copyright } \\
\text { and patents. }\end{array}$ & $\begin{array}{l}\text { - Standard business plans. } \\
\text { - Templates for financial analysis for } \\
\text { clients. } \\
\text { - Need a marketing plan template to } \\
\text { assist customers to draw up a cus- } \\
\text { tomized marketing plan. } \\
\text { - Template to assist customer in pre- } \\
\text { paring a financial statement. }\end{array}$ \\
\hline
\end{tabular}




\begin{tabular}{|l|l|l|}
\hline Technology Support & $\begin{array}{l}\text { - Maintenance on equip- } \\
\text { ment in the Centre. }\end{array}$ & $\begin{array}{l}\text { - Need Computer Based Material to } \\
\text { assist staff and clients on PC support } \\
\text { and maintenance aspects. } \\
\text { - Books and software that could assist } \\
\text { with technical aspects on computer } \\
\text { and networks. }\end{array}$ \\
\hline $\begin{array}{l}\text { Government } \\
\text { Information }\end{array}$ & $\begin{array}{l}\text { - Government Tenders. } \\
\text { - Funding opportunities } \\
\text { for the Centre. }\end{array}$ & $\begin{array}{l}\text { - Government information on funding } \\
\text { programmes. }\end{array}$ \\
\hline - Government Tenders.
\end{tabular}

Based on the above feedback a business model was developed electronically to assist them.

\section{The Business Model}

The operational and business model is based on defining the income-generating potential of the main operational components. The main operational components are:

- Telecentre Components with an income generating potential;

- Desktop Publishing Components with an income generating potential;

- Training Components with an income generating potential;

- Business Support (SMME) Components - with an income generating potential.

- Technology to support the main operational component.

The basic income generating components of an ICT equipped community centre could be illustrated graphically as in Figure 1.

Each major component provides a range of services to the community at a fee. The typical transaction value of the components of service delivery follows an exponential increase from R1 through to R500 as illustrated in Figure 1.

The low-cost, high volume business found in the first two components (Telecentre and Desktop Publishing services) can create the fundamental cash flow needed to support the higher-level activities (Training and Business support). These elements have been combined with anticipated volumes of transactions to arrive at the target income and other aspects of the business plan, to analyse the potential for the rural community centre to support itself as a self-sustaining business. It could also reduce the digital divide (Jacobs, 2003, pp. 108-138). 


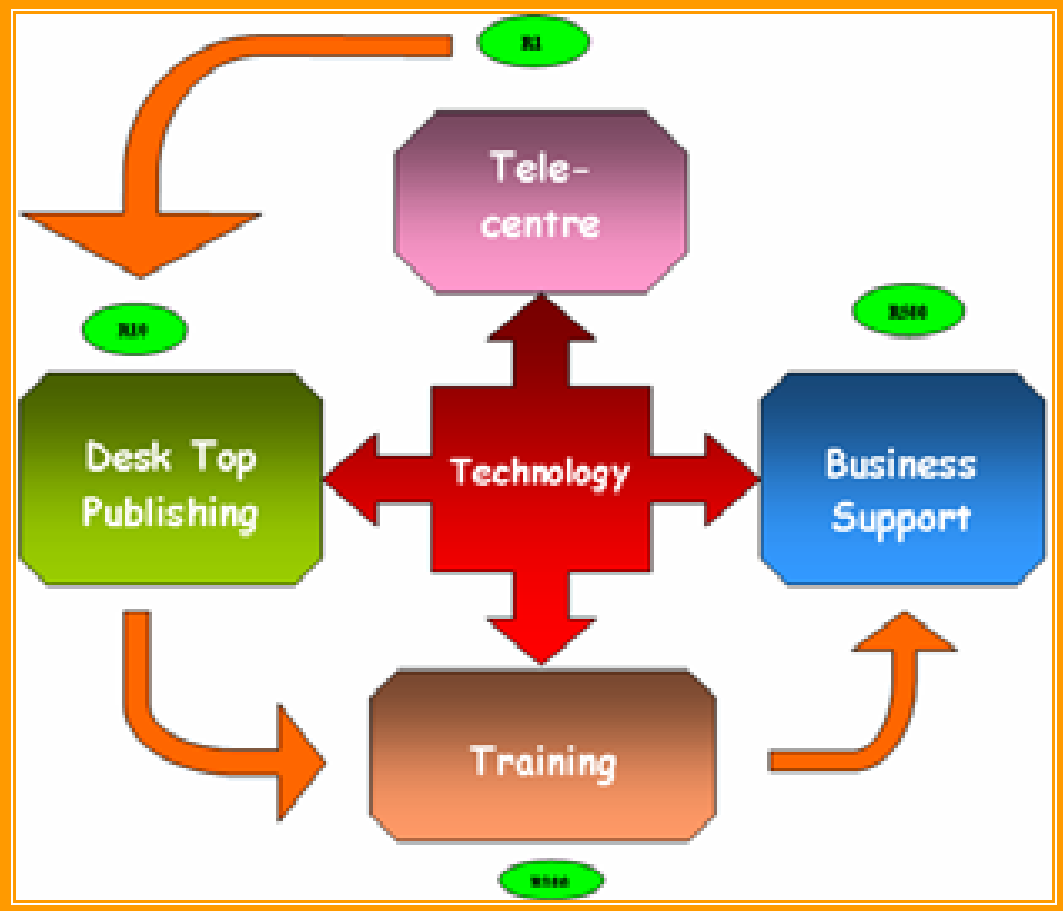

Figure 1: ICT-Hub Income Generating Components

Source: Adapted from Conradie, Morris \& Jacobs (2003:212)

Figure 2 is the electronic version of the business model for rural community centres as illustrated in Figure 1 above.

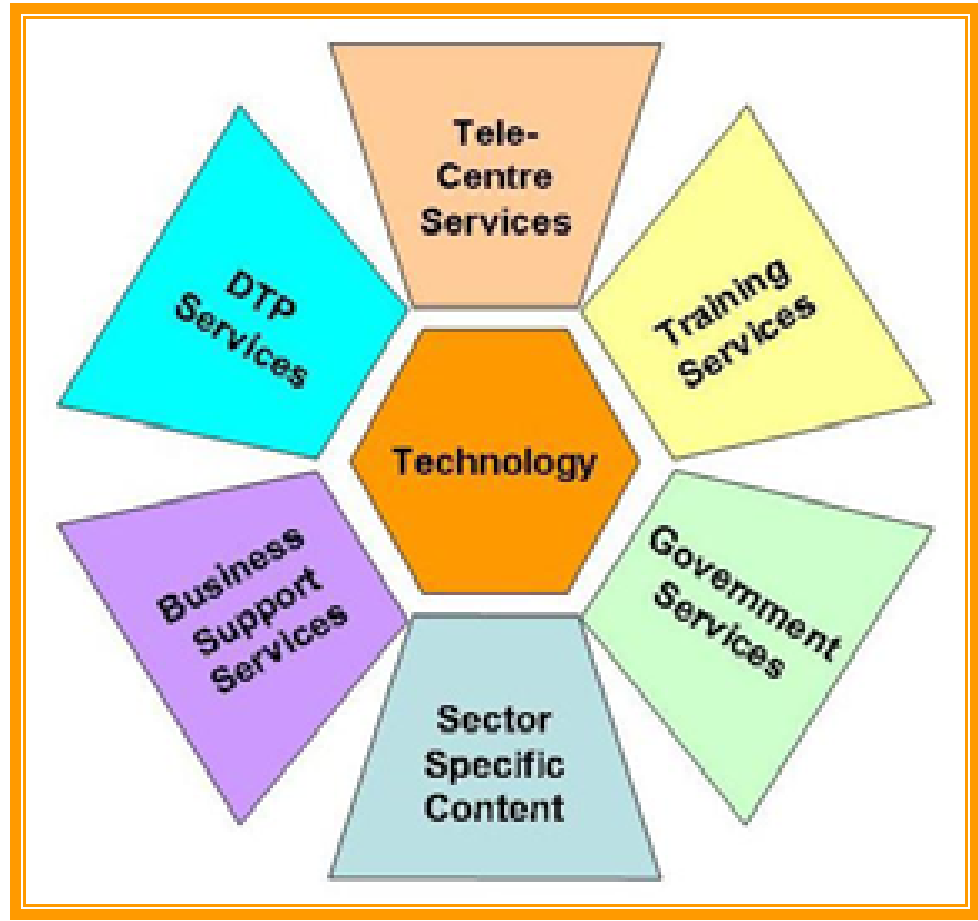

Figure 2: Community centre Operational Components Source: Adapted from Jacobs (2003:197). 
The electronic business model was designed to be a user-friendly information system and support tool for the management, staff and users within a rural community centre. The operational and business model was based on defining the income-generating potential of the various operational service delivery components of a rural community centre as previously discussed. The main operational components of the electronic version are the same as for the illustration in Figure 2; accept for adding two extra operational components to support the need of the community, namely:

- Sector Specific Content containing information regarding agricultural, health and educational aspects identified by the community centre staff and management (locally adapted content and context).

- Government Services contain links to government related websites for information purposes (content).

Throughout the research it became evident that a need exist within the Ikageng community centre to develop an electronic system that are fully interactive and easy to use by the centre staff and management. The level of complexity of the information in the system as well as the usage of the system must be equal to the level that the users at the community centre.

\section{Conclusion}

The results from the research indicated that a need exist for an electronic system that can support community centre staff and management to provide a more repeatable service to the customers (community members) to improve service delivery. It is important to note that this study was only conducted at one centre and that needs of communities differ when it comes to access to information for their own development or advancement. The results from this study further indicated that such a system must have a logical or systematic approach to service customer and staff needs and focus on relevant local content.

It is evident from the results obtained in this study that information contained in any type of electronic system must take care of two sets of information, namely:

- $\quad$ customer support content and

- centre support content for staff and management.

It is therefore evident that ICT-equipped community centres can be instrumental in the development and well-being of a community. Not only can they provide people with access to information related to health, nutrition, education, agriculture and other social basic necessities, they can support local entrepreneurs with various business services, market information, and e-commerce opportunities; they can help people connect with distant family, friends, and government officials; and they can provide a setting for entertainment and social affairs. It is important to note that not all information should be electronic and that rural community centre's should also make use of posters or billboard displays to communicate valuable information.

It is therefore essential that ICTs be demystified and deployed with the interests of local communities in mind. An example of a success in this regard was the Information Kerala Mission of 1997 in India where the State-level Informatics System for Strengthening the Decentralized Plan Implementation (SLIDE), government decision-makers throughout India realized the important role that ICTs would play in modern governance. Focused on creating efficient and responsive mechanisms for governance at the local level, the SLIDE project employed a variety of ICTs to help local institutions mitigate the transition to a decentralized governing system that is unique to the State. It was seen as one of the biggest technology literacy-building programmes in India.

By engaging Government officials and members of civil society, the electronic business model initiative promises to strengthen the Ikageng community centre's position as a high-technology 
Information Access for Development

centre in the country, while enhancing the states' profile in the global economy just as the Kerala project in India.

\section{References}

Burns, B.R. (2000). Introduction to research methods. London: SAGE Publications.

CIDA strategy on Knowledge for development through information and communication technologies. (2005). Accessed: 2005/03/03 at http://www.acdi-cida.gc.ca/ict

Conradie, D.P. \& Jacobs, S.J. (2003). Challenges encountered when using ICTs (Information and Communication Technologies) in support of development in rural African communities. Engineering Management, February, 30-33.

Cosh, A. \& Hughes, A. (2000). The British enterprise in transition: Growth, innovation and public policy in the small and medium sized enterprise sector 1994-1999, ESRC Centre for business research, University of Cambridge.

Cullen, R. (2002). Addressing the digital divide. Online Information Review, 25(5), 311-320.

Deakins, D. Galloway, L. \& Mochrie, R. (2004). The use and effect of ICT on Scotland's rural business community. Accessed: 2005/03/08 at http://scholar.google.com/scholar?hl=en=lr=\&safe=off \&q=cache:03MvBO7w_4MJ:ww

Freshwater, D. (2001). Delusions of grandeur: The search for a vibrant rural Merica. University of Kentucky, TVA rural studies programme. Kentucky Publishers.

Friedlander, A. (2001). Networked technologies and the Internet: A brief historical perspective. Washington, DC: Benton Foundation.

Fuller, E. \& Southern, A. (1999). Small firms and information and communication technologies: Policy issues and some words of caution. Environment and planning: Government Policy, 17, 287-302.

Gómez, R. \& Hunt, P. (1999). IDRC Telecentre Evaluation: A Global perspective. Report of an International Meeting on Telecentre Evaluation. Far Hills Inn, Quebec, Canada, 28-30 September 1999.

Harris, R. W. Sa. (2005). Evaluating Telecentre within National Policies for ICTs in Developing Countries. Accessed 2005/11/20 at http://www.idrc.ca/telecentre/evaluation/nn/18_Eva.html

Heeks, R. (1999). Information and communication technologies, poverty and development. Development Informatics Working Paper Series Working Paper No. 5 (ISBN: 19025 1826 8). Accessed 2005/11/23 at http://www.man.ac.uk/idpm/di_wp5.htm

Huggins, R \& Izushi, H. (2002). The digital divide and ICT learning in rural communities: Examples of good practice service delivery. Local Economy, 17, 111-122.

ITU. (2002). Bridging the digital divide in rural and remote communities: The Canadian Experience. World telecommunication development conference, Istanbul, Turkey, 18-27 March 2002. Accessed 2005/03/03 at www.wtdc-02/info/006V3E.doc

Jacobs, S.J. (2003). An information and communication technology hub for rural communities. (Unpublished: M Tech Dissertation) Pretoria: Tshwane University of Technology.

Mitchell, S. \& Clark, D. (1999). Business adoption of information and communications technologies in the two-tier rural economy: Some evidence from the South Midlands. Journal of Rural Studies, 15, 447455.

Mncube, S.S. (2003). The role of information in development. Development Bank of Southern Africa. Halfway House, South Africa.

Naidoo, K. (2005). Civil society. Sangonet Conference, 103 March 2005, Fourways, Johannesburg.

Olivier, M. S. (2004). Information technology research: A practical guide for computer science and informatics (Second Edition). Pretoria: Van Schaik Publishers. 
Ramirez, R. (2001). A model for rural and remote information and communication technologies: A Canadian exploration. Telecommunications Policy, 25(5), 315-330.

Rao, S.S. (2003). Information systems in Indian rural communities. Journal of Computer Information Systems, 44, 48-56.

Roberts, S. (2002). Key drivers of economic development and inclusion in rural areas. London: DEFRA.

Sebusang, S.E.M. \& Masupe, S. (2003). ICT development in Botswana: Connectivity for rural communities. The South African Journal of Information and Communication, 4, 41-51. LINK Centre, Witwatersrand University, South Africa, Johannesburg.

Smallbone, D., North, D., Baldock, R. \& Ekamen, I. (2002). Encouraging and supporting enterprise in rural areas. Middlesex University Business School Research report for the DTIs small business service, London.

Sparks, A. \& Thomas, B. (2001). The use of the Internet as a critical success factor for the marketing of Welsh agri-food SMEs in the twenty-first century. British Food Journal, 103, 331-347.

Warren, M. (2000). Farmers, computers and the Internet in contrasting areas in the UK: Implications for rural development. Plymouth: University of Plymouth.

Welman, J.C. \& Kruger, S.J. (2004). Research methodology. Oxford, New York: Oxford University Press.

United Nations Development Programme (UNDP). (1996). Report on the Workshop on Governance for Sustainable Human Development. MDGD, New York. April 1996.

United Nations Development Programme (UNDP). (1999). Human Development Report 1999: Globalisation with a human face. UNDP, Geneva.

World Bank. (1998). Harnessing Information for Development. World Bank, Washington D.C.

Yin, R.K. (1994). Case study research: Design and methods. London: Sage Publications.

\section{Biographies}

SJ Jacobs studied Electrical Engineering (Light Current) at the School of Electronic and Electrical Engineering at the Cape Technikon from 1988 till 1991, where he obtained a National Diploma in Electrical Engineering in 1990, and a National Higher Diploma in Electrical Engineering in 1991.

In 2003 he obtained his Master's Degree (cum laude) at the Faculty of Information and Communication Technology (ICT) at the Tshwane University of Technology. The title of his dissertation was: An Information and Communication Technology Hub (ICT-Hub) for Rural Communities. He received an award from the ICT Faculty in the category for bridging the digital divide.

In 2004 SJ enrolled for a Doctorate in Technology at the Tshwane University of Technology, and successfully completed his qualification, with the title of his thesis: A Quality Management System for Rural Community Centers.

Throughout his post graduate studies at TUT, SJ received bursaries from the National Research Foundation (NRF) to support his research activities.

Since 2000, he has received 8 merit awards, published 6 articles in peer-review/accredited journals, and presented 6 papers at various national/international conferences. Presently he supervises two master's students and one doctorate student at TUT.

SJ started his career at the Council for Scientific and Industrial Research (CSIR) as a student in training in 1989. 
In 2002 he left the CSIR as a senior project manager, responsible for managing multi-disciplinary and multimillion rand rural development projects, to join the then Technikon Pretoria as a project manager, responsible for technology transfer.

At present he is the Director of the Technology Station in Electronics (TSE) at TUT's Faculty of Engineering. The TSE's focus is to stimulate SME development and technology transfer in the electronic/electrical and ICT sectors.

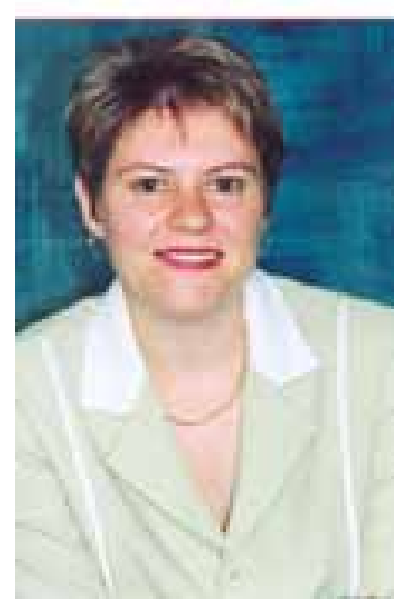

Prof Marlien Herselman is an Associate Research Professor of the Faculty of Information and Communication Technology. She assists lecturers and postgraduate students in research projects, National Research Foundation (NRF) projects, in writing research articles, and in other research-related activities. She obtained her PhD at the University of Pretoria in 1999. Her PhD studies focused on the use of computer games. She is currently busy with research on ICT usage in rural communities in South Africa with a National Research Foundation funded project.

In 2000, Prof Herselman was awarded a scholarship of the Deutsche Akademischer Austauschdienst (DAAD) of the International Women's University (IFU) to attend a summer semester at the University of Hamburg, in the project field of information.

In 2005 she received the prize as Women Researcher of the Year 2004 at Tshwane University of Technology.

\section{Research outputs:}

- Thriteen accredited journal publications

- Nine peer-reviewed published conference proceedings

- Four technical reports

- Fifteen contributions at international conferences

- One Chapter in a book

\section{Field of expertise}

- Technology in Higher Education

- ICT bridging the digital divide

- E-learning and ICT

- Business Information Systems 